Part of Journal of Research of the National Bureau of Standards, Volume 31, October 1943

\title{
THE ASSAY OF POTASSIUM p-PHENOLSULFONATE, ITS pH RANGE, AND ITS ULTRAVIOLET ABSORPTION SPEC- TRUM
}

\author{
By Elizabeth E. Sager, Marjorie R. Schooley, and S. F. Acree
}

\section{ABSTRAC'T}

Potassium $p$-phenolsulfonate is a good buffer for the pH range of 8.4 to 9.2 and for spectrophotometric studies of metacresolsulfonphthalein and thymolsulfonphthalein. Its useful $\mathrm{pH}$ range lies between those for borates and secondary phosphates and therefore fills an important gap. The purified product is not commercially available and quantitative tests for indicating its purity have not been reported. It was found that a pure product may be obtained after only three recrystallizations. A quantitative method of analysis by bromometric titration was developed. Two molecules of bromine react quantitatively with 1 molecule of $p$-phenolsulfonate in molar hydrochloric acid at $0^{\circ} \mathrm{C}$ within 5 minutes.

Ultraviolet absorption spectra were obtained and showed differences between the primary and the secondary salt. The spectrophotometric data indicate that the sulfonate group is almost completely ionized in dilute solutions.

CONTENTS

I. Introduction

II. Purification of potassium $p$-phenolsulfonate

III. Bromometric assay of potassium $p$-phenolsulfonate $\ldots \ldots \ldots . . . . . . .198$

1. Reagents _.......... 199

2. Experimental procedure $\ldots \ldots \ldots$

IV. Spectral absorption in the ultraviolet by potassium $p$-phenolsulfonate_- 200

\section{INTRODUCTION}

In spectrophotometric studies of indicators it is sometimes necessary to use buffers to stabilize the solutions which cover the $\mathrm{pH}$ and colorimetric transformation ranges. It is especially important that the compounds used as buffers and the indicators do not react or have overlapping absorption bands. The phenolsulfonates and some of their halogenated derivatives have been suggested ${ }^{1}$ as components of a stable buffer system over a wide $\mathrm{pH}$ range.

Highly purified phenolsulfonates are not available commercially. However, some of the compounds can be easily recrystallized from water and hence can be purified in the laboratory. After preliminary investigations of the potassium, sodium, calcium, and zinc salts of $p$-phenolsulfonic acid and of several salts of halogenated derivatives, potassium $p$-phenolsulfonate was chosen for more detailed study. The fact that it is anhydrous makes it more desirable than the sodium salt. The latter crystallizes with 2 molecules of water, which can be removed by drying but are taken up again at room temperature at

\footnotetext{
1 S. F. Acree, R. R. Mellon, B. M. Avery, and E. A. Slagle, A stable single buffer solution pH 1 to 12. J. Infectious Diseases 29, 7 to 10 (1921).
} 


\section{Journal of Research of the National Bureau of Standards}

humidities as low as 40 and 50 percent. Two samples of the recrystallized potassium salt lost 0.02 and 0.03 percent in weight when heated at $110^{\circ} \mathrm{C}$ for 24 hours and regained about the same amount over a period of 10 days, during which they were exposed from time to time in air of 40- to 50-percent humidity. Bromometric assay, by the procedure described later, showed no change in purity of the samples heated at $110^{\circ} \mathrm{C}$ for 24 hours. The same was true of a $10^{-2}$ molar solution which stood on the laboratory bench for 2 months. After heating at about $167^{\circ} \mathrm{C}$ for 20 hours, however, three samples lost 0.30 to 0.36 percent in weight and were found to contain sulfate. Bromometric analysis showed these samples to be 99.7 percent pure.

There apparently is no oxidation-reduction or other adverse reaction with the sulfonphthalein indicator series, as indicated by spectrophotometric curves, using $10^{-2}$ molar potassium $p$-phenolsulfonate buffers with metacresolsulfonphthalein and thymolsulfonphthalein.

\section{PURIFICATION OF POTASSIUM $p$-PHENOLSULFONATE}

The $p$-phenolsulfonate received from the manufacturer was a pinkish-white crystalline powder with a distinct phenolic odor. Impurities were removed before the first crystallization by treating a hot solution for about 10 minutes with an activated carbon. To remove all the carbon, the solution was filtered several times while hot. Each recrystallization was made by adding just enough hot water (about $80^{\circ}$ to $90^{\circ} \mathrm{C}$ ) to dissolve the crystals. The solution was then cooled to about $10^{\circ} \mathrm{C}$, and the crystals were filtered with suction but not allowed to dry between recrystallizations. A yield of about 40 percent for each recrystallization was obtained. The first mother liquor was pinkish and contained a small amount of sulfate. The subsequent mother liquors were colorless and sulfate tests were negative.

Two separate lots of potassium $p$-phenolsulfonate were recrystallized four and six times, respectively. Some material from each recrystallization was reserved for experimentation and dried for 2 hours in a vacuum oven at $2-\mathrm{mm}$ pressure and $60^{\circ} \mathrm{C}$. Analyses of the recrystallized product by micromethods for hydrogen, carbon, and sulfur, made by K. D. Fleischer of this Bureau, gave the following results: Found: C, $34.02,34.03 ; \mathrm{H}, 2.40,2.57$; S, $14.92,15.04$. Theoretical: $\mathrm{C}, 33.95 ; \mathrm{H}, 2.37$; $\mathrm{S}, 15.10$.

\section{BROMOMETRIC ASSAY OF POTASSIUM $p$-PHENOLSULFONATE}

Previous work on furfural and related compounds ${ }^{2}$ showed that under controlled conditions of acidity and temperature the reaction of bromine with some organic compounds can be used as a method for their quantitative determination. Preliminary experiments indicated that the reaction of bromine with phenolsulfonate gives slightly high results at room temperature. However, using essentially the method previously reported for furfural, it was found that at $0^{\circ} \mathrm{C} 2$ molecules of bromine react within 5 to 10 minutes with 1 molecule of $p$-phenolsulfonate in normal hydrochloric acid to form 2,6-dibromophenol4 -sulfonate and 2 molecules of hydrobromic acid. The reagents used and experimental procedure are given below.

${ }^{2}$ Elizabeth E. Hughes and S. F. Acree, Quantitative determination of furfural at $0^{\circ} \mathrm{C}$ with bromine, Ind Eng. Chem. 6, 123 (1934); Volumetric estimation of 5-bromo-2-furoic acid with bromine, Ind. Eng. Chem.6, 292 (1934). 


\section{REAGENTS}

Potassium bromate was recrystallized three times from water, and $5.567 \mathrm{~g}$ was used to make a solution approximately $0.2 \mathrm{~N}$, which contained $50 \mathrm{~g}$ of potassium bromide in $1 \mathrm{~kg}$ of water. The bromatebromide solution was used on a weight basis to standardize in normal hydrochloric acid through iodine the $0.1 \mathrm{~N}$ thiosulfate solution used for the titrations. The weighed amount of the bromate-bromide delivered by a special 25 -ml pipet with curved tip was reproducible within 0.05 percent. A solution of potassium iodide, about 10 percent by weight, was prepared freshly before use. Hydrochloric acid was used to make the reacting solution about normal in acidity. The potassium bromide, potassium iodide, and hydrochloric acid conformed to specifications of the American Chemical Society. ${ }^{3}$ As an additional check, the thiosulfate was standardized against potassium dichromate, recrystallized twice, using the same procedure described below. The two methods of standardization agreed within 0.1 percent.

\section{EXPERIMENTAL PROCEDURE}

Specially designed titration flasks, described previously (see footnote 2), were fitted with two side-arms for the bromate and iodide solutions, respectively. By means of pipets with curved tips, $25 \mathrm{ml}$ of the $0.2 \mathrm{~N}$ bromate-bromide solution was placed in one side-arm and 10 $\mathrm{ml}$ of the potassium iodide solution in the other. A known amount of phenolsulfonate was transferred to the body of the flask and diluted to about $200 \mathrm{ml}$. The solution was made normal in acidity by the addition of hydrochloric acid, using extreme care that the fumes did not reach the bromate in the side-arm. Blanks of the reagents were prepared in a similar manner, substituting water for the phenolsulfonate. Each flask was closed with a ground-glass stopper and placed in an icebox to attain a temperature of $0^{\circ}$ to $2^{\circ} \mathrm{C}$.

The reaction was started by tilting the flask so that the bromatebromide solution ran into the body of the flask, and the contents were gently swirled to mix the liberated bromine with the phenolsulfonate without disturbing the potassium iodide solution in the other side-arm. A stop watch was used to time the reaction, which was stopped by the addition of the potassium iodide. The contents were thoroughly shaken to absorb any bromine vapors, and the iodine equivalent to the residual bromine was titrated with $0.1 N$ thiosulfate, using starch as an indicator. At $0^{\circ} \mathrm{C}$ the discharge of the blue color at the end point was very definite, but it was found that the titration must be made as rapidly as possible. The blue color returns after several minutes, and consequently error may be introduced if the titration is prolonged. Experiments over a period of several hours, in which the blue color was discharged with thiosulfate as soon as it returned, showed that this error was of the order of $0.01 \mathrm{ml}$ per minute at low temperatures and twice this amount at room temperatures.

The amount of bromine consumed by the phenolsulfonate is determined from the difference between the amounts of standard thiosulfate solution used in titrating the blank and the solution containing the phenolsulfonate. The figures in table 1 for "percent reaction" are calculated on the assumption that in the desired reaction 1 mole of the phenolsulfonate consumes 2 moles of bromine.

\footnotetext{
${ }^{3}$ ACS Analytical Reagents. (American Chemical Society, Washington, D. C., March 1941).
} 
TABLE 1.-Reaction of potassium p-phenolsulfonate with bromine at $0^{\circ} \mathrm{C}$ in normal hydrochloric acid

\begin{tabular}{|c|c|c|c|c|}
\hline \multirow{2}{*}{$\begin{array}{l}\text { Time } \\
\text { allowed } \\
\text { for } \\
\text { reaction }\end{array}$} & \multicolumn{2}{|c|}{$\begin{array}{c}0.1698 \mathrm{~g} \text { of } \\
\text { potassium } p \text {-phenolsulfonate }\end{array}$} & \multicolumn{2}{|c|}{$\begin{array}{c}0.2124 \mathrm{~g} \text { of } \\
\text { potassium } p \text {-phenolsulfonate }\end{array}$} \\
\hline & $\begin{array}{c}\text { Milliequiva- } \\
\text { lents of } \\
\text { bromine } \\
\text { consumed }\end{array}$ & $\begin{array}{l}\text { Percentage } \\
\text { of reaction }\end{array}$ & $\begin{array}{l}\text { Milliequiva- } \\
\text { lents of } \\
\text { bromine } \\
\text { consumed }\end{array}$ & $\begin{array}{l}\text { Percentage } \\
\text { of reaction }\end{array}$ \\
\hline$\underset{2}{\text { Minutes }}$ & & & 3. 937 & 98.4 \\
\hline 5 & 3.195 & 99.9 & $\begin{array}{l}3.922 \\
\text { 4. } 001\end{array}$ & $\begin{array}{r}98.0 \\
100.0\end{array}$ \\
\hline 10 & 3. 199 & 100.0 & 4. 006 & 100.1 \\
\hline 15 & $\begin{array}{l}3.200 \\
3.199\end{array}$ & $\begin{array}{l}100.0 \\
100.0\end{array}$ & $\begin{array}{l}\text { 4. } 002 \\
\text { 4. } 004\end{array}$ & $\begin{array}{l}100.0 \\
100.0\end{array}$ \\
\hline 20 & 3.205 & 100.1 & & 100.1 \\
\hline 30 & $\begin{array}{l}\text { 3. } 207 \\
\text { 3. } 210\end{array}$ & $\begin{array}{l}100.2 \\
100.2\end{array}$ & - & - \\
\hline 120 & $\begin{array}{l}\text { 3. } 256 \\
\text { 3. } 256\end{array}$ & 101. 8 & 4.025 & 100.6 \\
\hline 180 & - & - & 4. 038 & 100.9 \\
\hline
\end{tabular}

The values in table 1 show the variation with time in the consumption of bromine at $0^{\circ} \mathrm{C}$ by two concentrations of phenolsulfonate. In all cases there were approximately 5.0 milliequivalents of bromine available, requiring $50 \mathrm{ml}$ of $0.1 N$ thiosulfate for titration of the blank. For the above amounts of phenolsulfonate, the excess bromine required about 18 and $10 \mathrm{ml}$ of thiosulfate, respectively. The table indicates that the reaction of 1 molecule of phenolsulfonate with 2 molecules of bromine is complete after about 5 minutes, and little additional reaction is noted until after 30 minutes. The figures for percentage of reaction show that the method is accurate to about 0.1 percent. A difference of $0.02 \mathrm{ml}$ in thiosulfate titration, representing in the above instances less than 0.1 percent, is possible due to the difference in time taken to add the $50 \mathrm{ml}$ for titration of the blank and that taken to add the smaller volume in the titration of the sample.

The values in table 2 show the analyses of the original material and the recrystallized fractions.

TABLE 2.-Bromometric assay of samples of potassium p-phenolsulfonate subjected to a series of recrystallizations

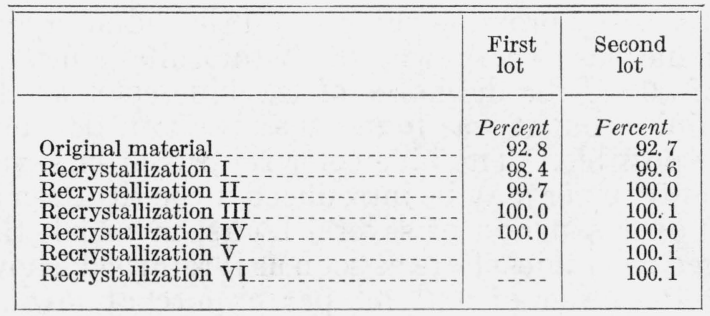

\section{SPECTRAL ABSORPTION IN THE ULTRAVIOLET BY POTASSIUM $p$-PHENOLSULFONATE}

In the spectrophotometric studies of indicators stabilized with $10^{-2}$ molar phenolsulfonate buffer, it was found that ultraviolet absorption spectra could not be obtained below $280 \mathrm{~m} \mu$, owing to the absorption bands of the buffer itself. A study therefore was made of the buffer without the indicator. Repeated dilutions of the phenol- 
sulfonate solutions were made and their transmittancy values measured until the main absorption bands were located. The series of spectral transmittancy values given in figure 1 represent concentrations of the phenolsulfonate in water from $10^{-2}$ molar (curve $A$ ) to $10^{-5}$ molar (curve $I$ ). The main absorption band, whose peak is at $230 \mathrm{~m} \mu$, is not sharply defined except in the more dilute solutions (curves $E$ through I). The transmittancy curves show bands similar to those of indicators.

Dilution of the phenolsulfonate with water immediately introduces the question of dissociation. At any wavelength the molar absorp-

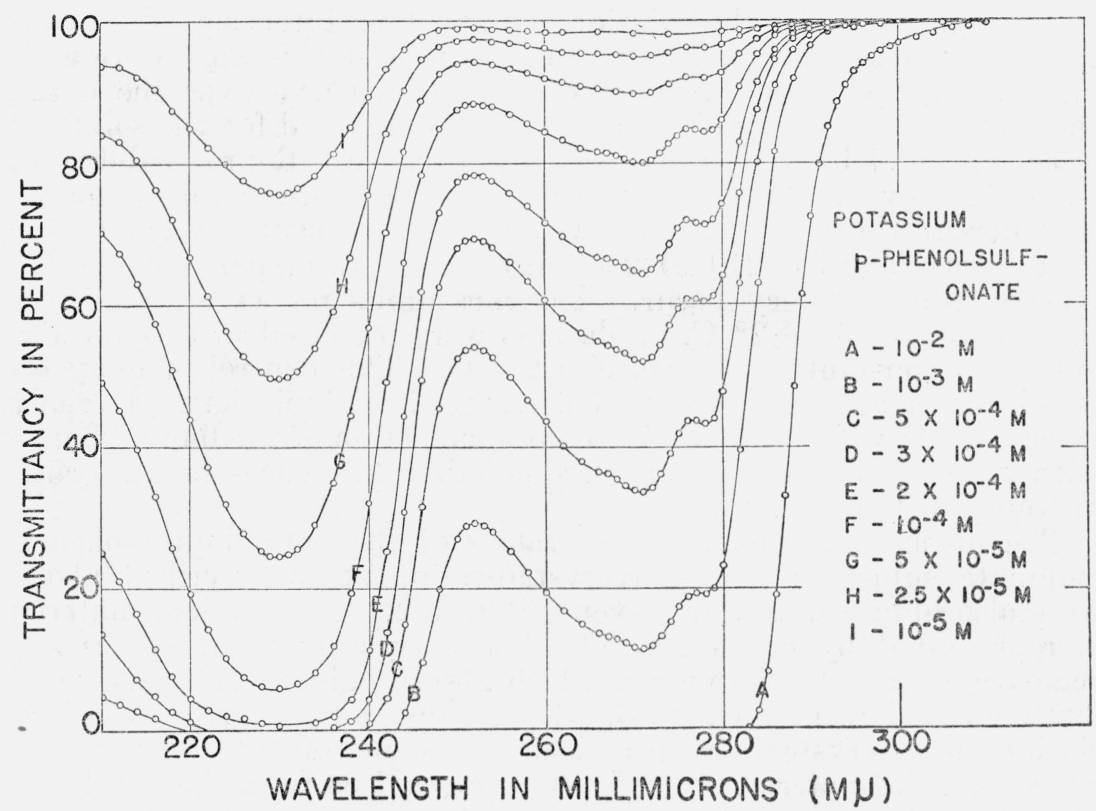

FiguRE 1.-Ultraviolet spectra of several concentrations of purified potassium p-phenolsulfonate.

tion index is determined by dividing the index ( $-\log _{10}$ transmittancy) for that solution by the concentration multiplied by the depth of the solution (cell length in centimeters) through which the light beam passes, according to Beer's law. If the molar absorption indices do not agree well within experimental error for several wavelengths, then dissociation, association, or some chemical change is suspected. For this purpose the absorption indices of solutions of phenolsulfonate $10^{-4}, 2 \times 10^{-4}$, and $3 \times 10^{-4}$ molar in water were first compared. Additional solutions of the same concentrations were made in $10^{-1}$ molar hydrochloric acid. These data agreed well within experimental error for practically the entire absorption curve, except on the steep portions of the bands where the errors are large, showing that the sulfonate group is completely ionized and the phenolic group nonionized in all the above solutions. As an additional check, a $10^{-4}$ molar solution in the $5-\mathrm{cm}$ cells was compared with a solution in the 1- and 2-cm cells. The agreement was well within experimental error.

The spectrophotometric data were obtained by use of a Beckman quartz photoelectric spectrophotometer. ${ }^{4}$ It was improved by the

4 Made by the National Technical Laboratories, Pasadena, Calif. Described in J. Opt. Soc. Am. 31, 682 (1941). 
replacement of the cell compartment ${ }^{5}$ by a small light-tight box with a slide for holding two 38-mm (i. d.) cylindrical metal cell holders in which Pyrex cylinders of 1-, 2-, and 5-cm lengths could be fitted with quartz end plates to hold the solutions. One cell was filled with the solution under investigation. The solvent, or 100-percent cell, contained the same components of the solution except the compound under investigation. The cells were placed alternately in the light beam for the transmittancy measurements. They were calibrated each day at the beginning and end of the test by filling both cells with distilled water, using the solvent cell for 100-percent transmission and reading the value for the solution cell at $10-\mathrm{m} \mu$ intervals from about 210 to $400 \mathrm{~m} \mu$. The quartz end plates used in this work were wellmatched and gave a satisfactory calibration curve over the entire spectral range. The transmittancy values obtained for the solutions were corrected by use of the calibration curve. Reproducibility of transmittancy values for a given concentration of solution prepared at different times was usually within \pm 0.2 percent, except at the lowest wavelengths $(210$ to $230 \mathrm{~m} \mu)$, where discrepancies of \pm 0.5 percent transmittancy occur. The measurements were made in a room kept at $25^{\circ} \pm 2^{\circ} \mathrm{C}$. Solutions were prepared in a room also kept at a constant temperature of $25^{\circ} \mathrm{C}$. This control of temperature is important in spectrophotometric studies of solutions, especially when the $\mathrm{pH}$ value of the solution and ionization of the buffer change with temperature, and cause corresponding differences in the transmittancy of the solution.

The ultraviolet transmittancy values of the potassium $p$-phenolsulfonate subjected to the recrystallization steps described above were also obtained and are given in figure 2. The original material is represented by curve $A$. The first recrystallization apparently removes most of the impurities which absorb light ${ }^{6}$ between 250 and $300 \mathrm{~m} \mu$, as shown by curve $B$, whereas the third, fourth, fifth, and sixth crops of crystals give practically the same transmittancy values, curve $C$. The material successively recrystallized from the first lot of phenolsulfonate showed a systematic change in the transmittancy values, as in the bromine analyses (given in table 2 but not shown in fig. 2).

Studies of a number of buffers have shown them to be highly resonant and chromophoric in the ultraviolet, and also that their absorption index bands are altered greatly by $\mathrm{pH}$ changes, just as in the case of indicators in the visible, ultraviolet, and infrared regions. Some measurements therefore were made of the ultraviolet absorption of solutions of the secondary $p$-phenolsulfonate salt, which is formed when alkali is added to a solution of the primary salt. The spectrophotometric curves shown in figure 3 represent the $p$-phenolsulfonate, $5 \times 10^{-5}$ molar, in $10^{-1}$ molar hydrochloric acid (curve $A$ ) and the same concentration in $10^{-3}$ molar sodium hydroxide (curve $D$ ). The two intermediate curves, $B$ and $C$, were obtained by using dilute borax-boric-acid buffers of $\mathrm{pH} 8.4$ and 9.0, which do not have absorption bands in this region. In these dilute solutions there may have been some error due to the absorption of carbon dioxide during the

\footnotetext{
${ }_{6}$ The authors are indebted to Jurg. A. Senn for help in designing the metal box, as well as other improvements in the electric circuit, and calibration of the instrument. Extensive data, which have not yet been reported, were obtained previously with filters and indicator solutions to test the performance of the instrument. The precision is about \pm 0.5 on the scale from 0.0 - to 100.0 -percent transmittancy.

${ }_{6}$ For example, figure 3 shows that any secondary salt present as impurity absorbs strongly between 240 and $300 \mathrm{~m} \mu$.
} 


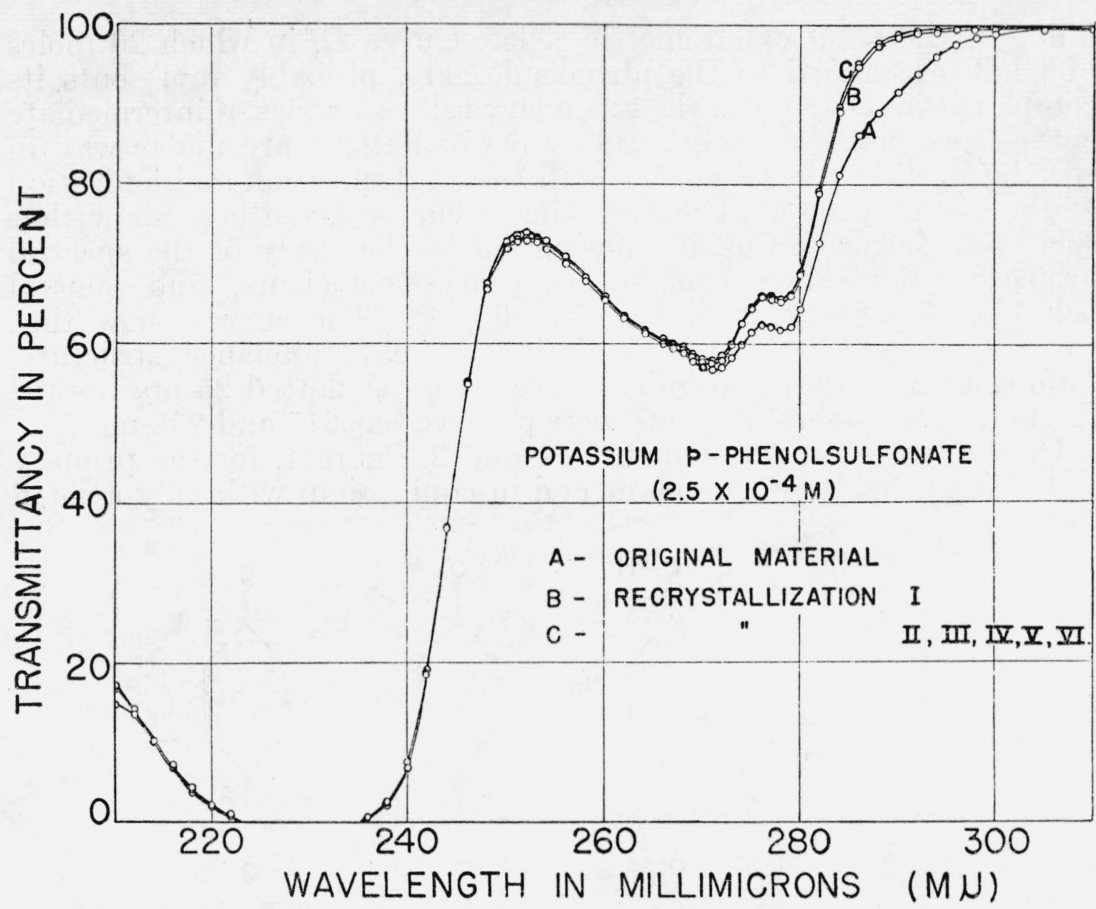

FIGURE 2.-Ultraviolet spectra of impure and recrystallized potassium p-phenolsulfonate.

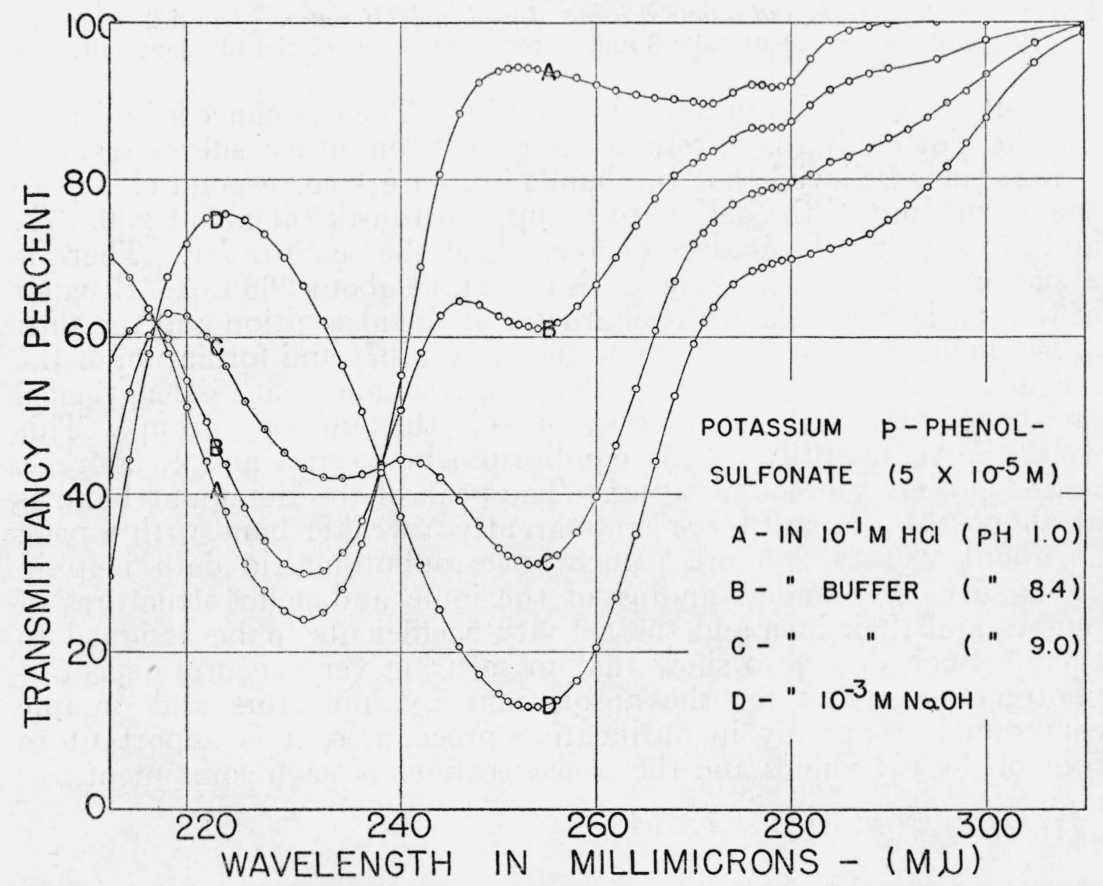

FIGURE 3.-Ultraviolet spectra which represent the transformation of potassium $p$-phenolsulfonate from the primary to the secondary salt. 
filling of the spectrophotometric cells. Curve $D$, in which 20 moles of alkali are added to the phenolsulfonate, probably represents its complete conversion into the secondary salt. A series of intermediate curves has since been obtained, and calculations are under way in correlating the spectral curves with the neutralization and ionization of the phenol group. The preliminary curves given here show that such data furnish valuable information in the study of the spectral properties, ionization constant, activity coefficients, and general behavior of such polar buffers (see fig. 4). The curves show that the secondary salt has an entirely different resonance structure, leading to an absorption index curve which is shifted $25 \mathrm{~m} \mu$ toward the red. Two isobestic points were observed at 215 and $238 \mathrm{~m} \mu$.

Of the two resonant structures 1 and 2 , figure 4 , for the primary salt, 2 is probably predominant and in equilibrium with only a small

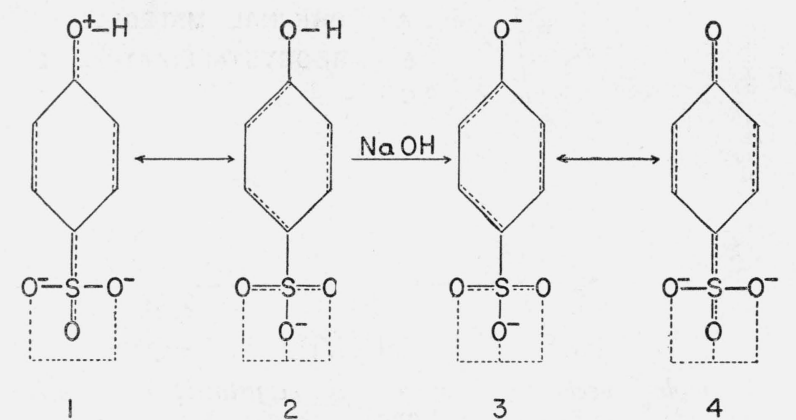

FIGURE 4.-Structural and resonant forms of p-phenolsulfonates. 1 and 2, resonant forms of the univalent salt; 3 and 4 , resonant forms of the bivalent salt.

amount of the dipolar quinoidal form of 1 . The resonance is indicated by the dotted lines. From similar data on other sulfonates and buffers, it is believed that the bands in figure 1 correspond chiefly to the absorption of the sulfonate group, with peaks at about 230,271, and $278 \mathrm{~m} \mu$ and the indices decreasing in the same order. There is apparently also a weak band with a peak at about $266 \mathrm{~m} \mu$. Because of the marked change in the character of the absorption and the shift of the band toward the red upon increase in $\mathrm{pH}$ and formation of the secondary salt, it seems likely that the resonance path is lengthened and hence extended considerably outside the sulfonate group. This would be represented by the equilibrium between 3 and 4 , figure 4 , with 4 probably predominating. The peak of the dominant band is at about $254 \mathrm{~m} \mu$, and there is apparently a weaker band with a peak at about 280 to $285 \mathrm{~m} \mu$. Such spectrophotometric data help in giving a clearer understanding of the ionic and polar structures of buffers and their ions and the activity coefficients to be assigned to them. Such data also show that in securing very accurate spectrophotometric values for the absorptions by indicators and organic compounds, especially in purification procedures, it is important to control the $\mathrm{pH}$ values and the concentrations of each component.

Washington, August 7, 1943. 